\title{
PEMANFAATAN ZEOLIT DALAM PENGOMPOSAN LIMBAH LUMPUR (SLUDGE) IPAL PT.X
}

\author{
Sri Yanti Lisha ${ }^{(1)}$, Nofriya ${ }^{(2)}$, Aprilia Melisa ${ }^{(3)}$ \\ Program Studi Teknik Lingkungan Sekolah Tinggi Teknologi Industri Padang \\ email : sriyantilisha@gmail.com
}

\begin{abstract}
Abstrak
Abstrak : PT.X merupakan industri minyak goreng sawit yang mengolah limbah dengan Instalasi Pengolahan Air Limbah (IPAL). IPAL PT.X menghasilkan limbah lumpur (sludge) yang belum dikelola dengan baik. Sludge berpotensi memiliki kandungan logam berat yang dapat diatasi dengan penambahan zeolit. Sludge dimanfaatkan sebagai kompos karena memiliki kandungan bahan organik tinggi. Tujuan penelitian menganalisis kualitas kompos dari sludge IPAL PT.X yang dibandingkan dengan SNI 19-7030-2004 dan mengetahui pengaruh variasi komposisi zeolit terhadap kandungan logam $\mathrm{Zn}$ kompos dari limbah lumpur. Analisis data dilakukan secara deskriptif dan membandingkan dengan SNI 19-7030-2004. Hasil penelitian ini menunjukan bahwa kompos dari sludge IPAL dengan penambahan zeolit terbukti efektif menghasilkan kompos yang memenuhi SNI 19-7030-2004 yang paling banyak pada variasi 3 (sludge $+30 \%$ zeolit) dengan temperatur $27.6^{\circ} \mathrm{C}$, berbau seperti tanah, kadar air 32.08\%, Karbon sebesar 22.950\%, Nitrogen sebesar 2.030\%, Rasio C/N sebesar 11.31, dari 9 parameter uji 3 diantaranya belum memenuhi standar SNI kompos, parameter pH sebesar 6.77, warna kompos yang dihasilkan coklat keabu-abuan, dan kandungan logam Zn sebesar $528.313 \mathrm{mg} / \mathrm{kg}$. Zeolit pada kompos sangat memberikan pengaruh terhadap kandungan logam $\mathrm{Zn}$ pada kompos yang dihasilkan namun masih belum memenuhi standar karena kemampuan zeolit dalam menyerap logam $\mathrm{Zn}$ lebih sedikit yang sesuai dengan deret selektivitasnya.
\end{abstract}

Kata kunci : IPAL, sludge, zeolit, kompos

Abstract : PT.X is a palm cooking oil industry that treats waste by using a Waste Water Treatment Plant (WWTP). It produces waste in the form of sludge that has not been managed properly. It contains potentially heavy-metals, which can be overcome by adding zeolites. It can be used as compost because it contains high organic matter. The purpose of the study is to analyze the quality of compost from PT.X WWTP sludge compared with SNI 19-7030-2004 and determine the effect of zeolite composition-variations on the Zn compost metal content of PT.X WWTP sludge waste. Data analysis is performed descriptively and compared with SNI 19-7030-2004. The results of this study indicatethat compost from WWTP sludge with the addition of zeolite has proven to be effective in producing compost that meets SNI 19-7030-2004 at most variations in 3 (sludge $+30 \%$ zeolite) with a temperature of 27.6 OC, smells like soil, 32.08\% water content, Carbon at 22,950\%, Nitrogen at 2,030\%, C / N Ratio at 11.31, from 9 test parameters 3 of which did not meet compost SNI standards, pH parameters of 6.77, compost color produced grayish brown, and Zn metal content of 528,313 $m g / k g$. The use of zeolite in compost gives numerous effects of the Zn metal content which has been produced, but it still does not fulfill the standards, because the capability of zeolite to absorb Zn metals is less than the selectivity series.

Keywords : WWTP, sludge, zeolite, compost

\section{PENDAHULUAN}

Peningkatan produksi minyak goreng sawit dapat dilakukan dengan pengembangan industri minyak goreng sawit di Indonesia. Ini sangat berkaitan dengan ketersediaan Crude Palm Oil
(CPO) sebagai input produksi minyak goreng di pasar domestik. Produksi CPO Indonesia telah mengalami pertumbuhan yang signifikan sejak tahun 1990 yang meningkat hingga 2015 dari hanya 2,4 juta 
ton menjadi 31,2 juta ton pada tahun 2015 (BPS, 2015).

Setiap pelaku industri minyak goreng menghasilkan limbah dari proses pengolahan CPO sampai menjadi minyak goreng berupa limbah cair. Limbah cair akan diolah dalam Instalasi Pengolahan Air Limbah (IPAL) untuk menurunkan kadar polutan dalam limbah tersebut sebelum dibuang ke aliran sungai. IPAL PT.X menghasilkan produk samping berupa limbah lumpur (sludge). Proses pengolahan air limbah yang terus berjalan mengakibatkan semakin meningkat pula jumlah limbah sludge yang dihasilkan IPAL. Limbah sludge PT.X belum dimanfaatkan sesuai potensinya dan penanganannya dan hanya sebagai open dumping. Sludge yang dibiarkan terbuka tanpa penanganan lebih lanjut akan berpotensi sebagai sumber pencemaran lingkungan yang akan menimbulkan bau tidak sedap. Salah satu upaya untuk mengatasinya adalah dengan memanfaatkan sludge IPAL sebagai bahan baku kompos, karena sludge memiliki kandungan bahan organik yang tinggi.

Limbah lumpur atau sludge merupakan salah satu limbah bahan berbahaya dan beracun (B3). Adapun logam berat yang terdapat pada sludge yang dihasilkan oleh industri minyak goreng menurut lampiran PP nomor 85 tahun 1999 adalah logam $\mathrm{Cr}, \mathrm{Ni}$, dan $\mathrm{Zn}$. Selain itu menurut peraturan pemerintah nomor 101 tahun 2014 tentang pengolahan limbah B3, sludge ipal termaksud dalam daftar limbah peraturan ini dengan kode B343-2. Oleh karena itu pemanfaatan limbah lumpur hasil pengolahan IPAL PT.X perlu dilakukan proses penetralan logam berat pada saat pengomposannya, agar kompos yang dihasilkan tidak berbahaya bagi tanaman (Astiana, 2004). Salah satu alternatif yang digunakan untuk penetralan logam berat pada limbah sludge adalah dengan penambahan zeolit sebagai bahan pencampuran dalam proses pengomposan.
Tujuan dari penelitian ini adalah menganalisis kualitas kompos dari limbah lumpur IPAL PT.X yang dibandingkan dengan SNI 19-7030-2004 dan mengetahui pengaruh variasi komposisi zeolit terhadap kandungan logam Zn kompos dari limbah lumpur IPAL PT.X.

\section{METODE PENELITIAN}

Adapun jenis penelitian ini adalah berbentuk eksperimen dengan menguji beberapa komposisi zeolit terhadap limbah lumpur (sludge) IPAL PT.X untuk memperoleh kompos. Setelah kompos matang, tahap selanjutnya pada penelitian ini adalah melakukan Uji laboratorium terhadap 9 parameter yang dipilih dari parameter-parameter yang ada pada SNI yaitu : nilai $\mathrm{pH}$, kadar air, temperatur, bau, warna, $\mathrm{N}$ total, $\mathrm{C}-$ Organik, Rasio $\mathrm{C} / \mathrm{N}$ dan $\mathrm{Zn}$ dengan membandingkan dengan SNI 19-7030-2004. Penelitian lokasi penelitian dilakukan di laboratorium PT. X.

Tabel 1. Paramater Uji Pengomposan Dengan Penambahan Zeolite

\begin{tabular}{|l|c|c|c|}
\hline Parameter uji & $\begin{array}{c}\text { Satu } \\
\text { an }\end{array}$ & $\begin{array}{c}\text { Minimu } \\
\mathrm{m}\end{array}$ & Maksimum \\
\hline 1. $\mathrm{pH}$ & & 6,80 & 7,49 \\
\hline 2. Kadar air & $\%$ & - & 50 \\
\hline 3. Temperatur & ${ }^{\circ} \mathrm{C}$ & & $\begin{array}{c}\text { suhu air } \\
\text { tanah }\end{array}$ \\
\hline 4. Bau & & & bau tanah \\
\hline 5. Warna & & & kehitaman \\
\hline 6. N Total & $\%$ & 0,40 & - \\
\hline 7. C-organik & $\%$ & 9,80 & 32 \\
\hline 8. Rasio C/N & $\%$ & 10 & 20 \\
\hline 9. Zn & $\begin{array}{c}\mathrm{Mg} / \\
\mathrm{kg}\end{array}$ & & 500 \\
\hline
\end{tabular}

Sumber : SNI 19-7030-2004

Komposisi bahan baku kompos seperti pada Tabel 2.

Tabel 2 Variasi Kompos

\begin{tabular}{|c|c|c|c|c|}
\hline $\begin{array}{l}\text { Vari- } \\
\text { asi }\end{array}$ & $\begin{array}{c}\text { Kompo- } \\
\text { sisi }\end{array}$ & $\begin{array}{l}\text { Jum- } \\
\text { lah } \\
\text { Sluge }\end{array}$ & $\begin{array}{l}\text { Jum- } \\
\text { lah } \\
\text { Zeolit }\end{array}$ & $\begin{array}{c}\text { Jum- } \\
\text { lah } \\
\text { EM4 }\end{array}$ \\
\hline 1 & $\begin{array}{l}\text { Hanya } \\
\text { Sludge }\end{array}$ & $15 \mathrm{~kg}$ & - & $\begin{array}{c}0.7 \\
\%\end{array}$ \\
\hline 2 & $\begin{array}{l}\text { Sludge }+1 \\
0 \% \text { zeolit }\end{array}$ & $\begin{array}{c}13.5 \\
\mathrm{~kg}\end{array}$ & $1.5 \mathrm{~kg}$ & $\begin{array}{c}0.7 \\
\%\end{array}$ \\
\hline
\end{tabular}




\begin{tabular}{|c|c|c|c|c|}
\hline 3 & $\begin{array}{c}\text { Sludge+3 } \\
0 \% \text { zeolit }\end{array}$ & $\begin{array}{c}10.5 \\
\mathrm{~kg}\end{array}$ & $4.5 \mathrm{~kg}$ & $\begin{array}{c}0.7 \\
\%\end{array}$ \\
\hline
\end{tabular}

Sumber : Penelitian

Jumlah zeolit yang diberikan untuk meningkatkan mutu kompos antara 10-30\% dari bahan kompos (Suwardi, 2019). Presentasi zeolit 10\% diambil untuk yang terendah dan presentasi zeolit 30\% diambil untuk yang tertinggi. Pada penelitian Gunadi Priyambada, dkk (2015) didapatkan varian optimun dengan penambahan $0.7 \%$ bioaktivator EM4. oleh karena itu pada penelitian ini pada masingmasing komposter dicampurkan dan ditambahkan 0,7\% bioaktivator EM4.

\section{Preparasi EM4}

Langkah-langkah persiapan EM4 adalah :

a. Campurkan $20 \mathrm{ml}$ EM4 asli dengan $20 \mathrm{ml}$ molases lalu ditambahkan air hingga tercampur menjadi $1000 \mathrm{ml}$

b. Masukan larutan yang telah jadi ke dalam wadah, lalu tutup hingga rapat

c. Biarkan 5-10 hari dalam keadaan kedap udara, wadah harus tertutup rapat dan terhindar dari sinar matahari langsung

d. Buka tutup wadah pada hari ke lima untuk mengeluarkan gas agar tidak meledak

e. Setelah 5-10 hari, EM4 aktif sudah dapat digunakan dengan diindikasi tercium bau asam manis, $\mathrm{pH}$ EM4 aktif berkisar 3.5-3.7

\section{Pembuatan kompos}

Proses pembuatan kompos adalah :

a. Menyiapkan 3 buah alat komposter.

b. Masukkan semua bahan limbah lumpur kedalam alat komposter.

c. Menambahkan zeolit pada setiap kompos dengan varian yang berbeda.

d. Selama pengomposan semprotkan bioaktifator, campuran harus sambil diaduk secara perlahan dan merata.

e. Membiarkan proses pengomposan selama lebih kurang 2 minggu dengan mengaduk bahan campuran setiap 1 kali sehari. f. Hingga didapatkan kompos matang yang dapat digunakan.

Pengomposan dilakukan secara aerob sampai kompos matang dengan ciri-ciri kompos yang berkualitas baik adalah berwarna kecoklatan, gelap hingga hitam, berbau tanah, partikel halus, $\mathrm{pH}$ normal, suhu kompos sama dengan suhu ruangan, dan tidak mengandung logam, kaca, ataupun plastik (Wildan Djaja ,2008) dan diukur kadar 9 parameter yang dibandingkan dengan SNI 19-7030-2014.
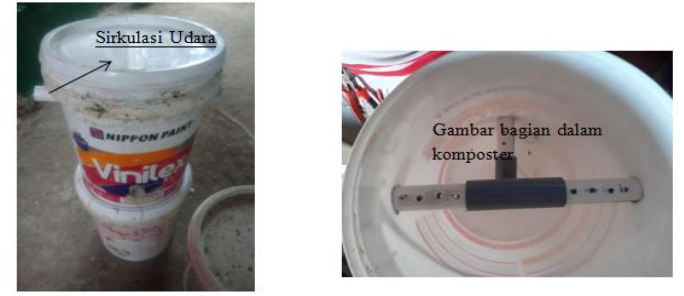

Gambar 1. Alat Komposter

\section{HASIL DAN PEMBAHASAN}

Kompos yang dihasilkan dari limbah lumpur IPAL PT.X dilakukan selama 14 hari masa pengomposan. Proses pengomposan ini dilakukan dengan komposter sederhana dalam kondisi aerob. Kompos telah matang berdasarkan SNI 197030-2004 pada hari ke 14 karena temperatur kompos sama dengan suhu air tanah, kompos warna kehitaman, berbau tanah. Setelah kompos matang maka dilakukan pengujian laboratorium terhadap 9 parameter yang dipilih. Hasil pengujian terlihat pada Table 3. Tabel ini menampilkan hasil pengujian 3 jenis variasi bahan baku kompos dengan variabel bebasnya $\%$ penggunaan zeolit.

Tabel 3. Hasil Uji 9 Parameter Komposisi Kompos Dibandingkan Dengan SNI

\begin{tabular}{|c|c|c|c|c|c|}
\hline $\mathrm{N}$ & $\begin{array}{c}\text { Para- } \\
\text { meter }\end{array}$ & $\begin{array}{c}0 \% \\
\text { zeolit }\end{array}$ & $\begin{array}{c}10 \% \\
\text { zeolit }\end{array}$ & $\begin{array}{c}30 \% \\
\text { zeolit }\end{array}$ & $\begin{array}{c}\text { SNI } \\
\text { Kompos }\end{array}$ \\
\hline 1 & $\mathrm{pH}$ & 5.61 & 6.39 & 6.77 & $6.80-7.49$ \\
\hline 2 & $\begin{array}{l}\text { Tempera- } \\
\text { tur }\end{array}$ & $27.7{ }^{\circ} \mathrm{C}$ & $27.8{ }^{\circ} \mathrm{C}$ & $27.6{ }^{\circ} \mathrm{C}$ & $\begin{array}{c}\text { Suhu air } \\
\text { tan max. } \\
30^{\circ} \mathrm{C}\end{array}$ \\
\hline
\end{tabular}




\begin{tabular}{|c|l|c|c|c|c|}
\hline 3 & Warna & $\begin{array}{c}\text { Kehi- } \\
\text { taman }\end{array}$ & $\begin{array}{c}\text { Coklat } \\
\text { Kehita } \\
\text { man }\end{array}$ & $\begin{array}{c}\text { Coklat } \\
\text { Keabu- } \\
\text { abuan }\end{array}$ & Kehitaman \\
\hline 4 & Bau & $\begin{array}{c}\text { Berbau } \\
\text { tanah }\end{array}$ & $\begin{array}{c}\text { Berbau } \\
\text { tanah }\end{array}$ & $\begin{array}{c}\text { Berbau } \\
\text { tanah }\end{array}$ & $\begin{array}{c}\text { Berbau } \\
\text { tanah }\end{array}$ \\
\hline 5 & Kadar Air & $\begin{array}{c}58.39 \\
\%\end{array}$ & $\begin{array}{c}47.98 \\
\%\end{array}$ & $32.08 \%$ & Max. 50\% \\
\hline 6 & Karbon & $\begin{array}{c}21.650 \\
\%\end{array}$ & $\begin{array}{c}20.300 \\
\%\end{array}$ & $\begin{array}{c}22.950 \\
\%\end{array}$ & $9.80-32 \%$ \\
\hline 7 & Nitrogen & $\begin{array}{c}2.450 \\
\%\end{array}$ & $\begin{array}{c}3.010 \\
\%\end{array}$ & $2.030 \%$ & Min 0.4\% \\
\hline 8 & Rasio C/N & 8.84 & 6.74 & 11.31 & $10-20$ \\
\hline 9 & Logam Zn & 714.79 & 648.06 & 528.31 & $\begin{array}{c}\text { Max 500 } \\
\text { Mg } / \mathrm{Kg}\end{array}$ \\
\hline
\end{tabular}

Sumber : hasil pengujian laboratorium.

Dari hasil penelitian diperoleh bahwa pada pengomposan $0 \%$ zeolit ada 4 parameter yang tidak terpenuhi baku mutu kompos yaitu $\mathrm{pH}$, kadar air, rasio $\mathrm{C} / \mathrm{N}$, dan logam Zn. Pada $10 \%$ zeolit masih ada 2 parameter yang belum memenuhi yaitu rasio $\mathrm{C} / \mathrm{N}$ dan logam $\mathrm{Zn}$. Dan pada penggunaan $30 \%$ zeolit hanya tertingga 1 parameter saja yang belum terpenuhi yaitu $\mathrm{Zn}$.

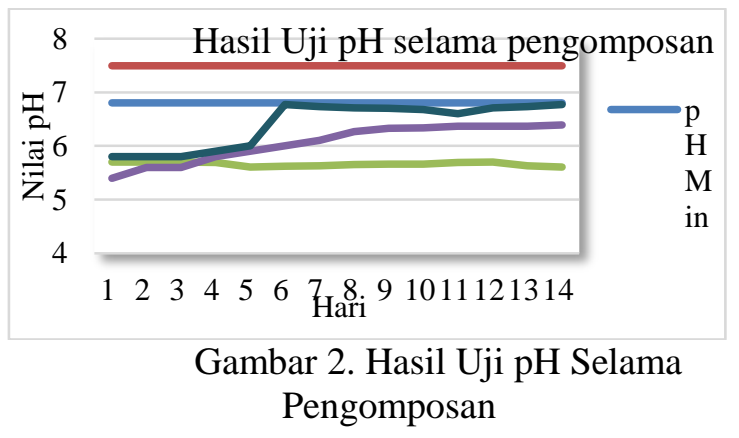

Kenaikan nilai $\mathrm{pH}$ pada tiga variasi diakibatkan dengan adanya penambahan zeolit pada kompos dengan komposisi zeolit $10 \%$ dan $30 \%$. Nilai $\mathrm{pH}$ yang didapatkan selama pengomposan terus meningkat dengan semakin tinggi jumlah zeolit yang diberikan dan semakin lama waktu pengomposan maka nilai $\mathrm{pH}$ pada kompos juga mengalami peningkatan, peningkatan $\mathrm{pH}$ oleh zeolit dimungkinkan karena kation-kation basa yang terdapat pada zeolit seperti $\mathrm{Ca}, \mathrm{K}$ dan $\mathrm{Mg}$ dapat dipertukarkan dengan ion $\mathrm{H}^{+}$dan $\mathrm{Al}^{+3}$ (Ano dan Ubochi, 2007). Peningkatan $\mathrm{pH}$ pada kompos dengan meningkatan kadar zeolit, hal ini di perkirakan dipengaruhi oleh kation-kation pada zeolit bersifat basa hal ini memungkinkan zeolit dapat mempengaruhi sifat asam pada kompos yang telah campurkan dengan zeolit (Ano dan Ubochi, 2007). Penelitian mendapatkan hasil pengukuran $\mathrm{pH}$ zeolit didapatkan nilai 8.8. Hal ini membuktikan bahwa zeolit bersifat basa. Hasil analisis pada $\mathrm{pH}$ kompos didapatkan perubahan nilai $\mathrm{pH}$ pada variasi 1 nilai $\mathrm{pH}$ sebesar 5.61, pada variasi 2 mengalami perubahan $\mathrm{pH}$ dari 5.61 menjadi 6.39 yang mengalami peningkatan karena mengunakan penambahan $10 \%$ zeolit dan variasi 3 nilai $\mathrm{pH}$ mendekati standar baku mutu sebesar 6.77 dimana standar $\mathrm{pH}$ nya adalah 6.80. Pada penelitian ini didapatkan kompos matang dengan bau kompos sama seperti tanah yang sesaui dengan ketentuan SNI 19-7030-2004 dengan ketentuan berbau seperti tanah.

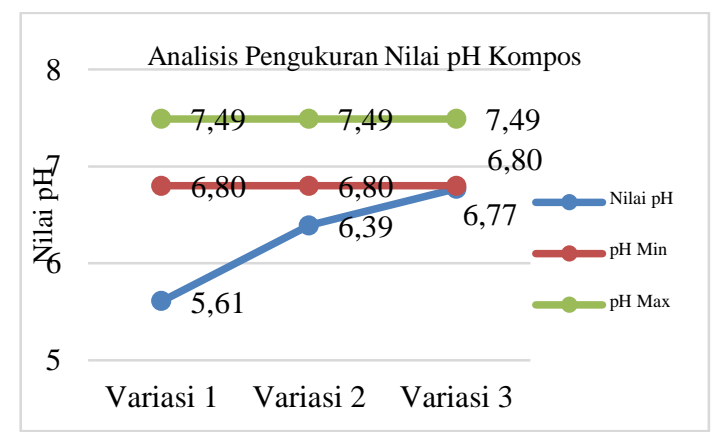

Gambar 3. Grafik Analisis Pengukuran Nilai pH Kompos

Sedangkan warna pada kompos yang sudah matang adalah lebih gelap. Perubahan warna dalam kompos tergantung dari bahan dasar yang digunakan (Widriyani, 2008). Sludge sebagai bahan utama yang diangkat dari limbah lumpur IPAL berwarna coklat kehitaman dan zeolit berwarna abu-abu. Dengan penambahan campuran zeolit 10 $\%$ tidak menganggu warna dari kompos, sedangkan pada penambahan campuran zeolit $30 \%$ mempengaruhi warna sehingga 
warna yang dihasilkan menjadi coklat keabu-abuan. Warna kompos dapat dilihat pada Gambar 4.
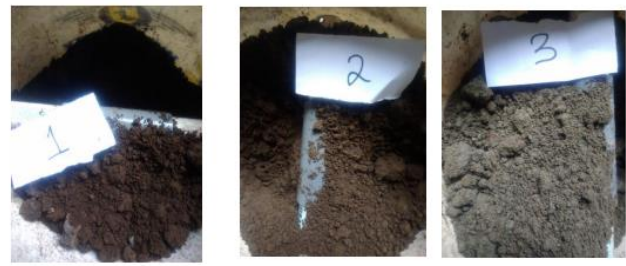

Gambar 4. Warna kompos

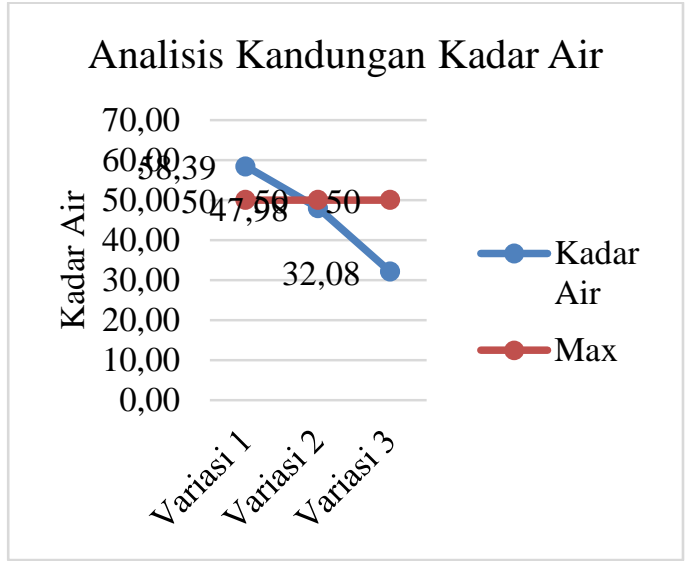

Gambar 5. Analisis Kadar Air

Berdasarkan hasil dari penelitian yang telah dilaksanakan didapatkan hasil pengukuran kadar air pada tiga variasi yakni variasi 1 sebesar $58.39 \%$, variasi 2 sebesar $47.98 \%$, dan variasi 3 sebesar $32.08 \%$. Perbedaan kadar air pada variasi 1, 2 dan 3 diakibatkan karena kurang maksimal proses pembalikan saat pengomposan berlangsung. Pembalikan memberikan sirkulasi udara segar yang diperlukan untuk mengurangi kadar air dan menghindari kondisi anaerob. Kondisi anaerob tidak diinginkan selama proses pengomposan karena akan dihasilkan bau yang tidak sedap. Proses aerobik akan menghasilkan senyawa-senyawa yang berbau tidak sedap seperi asam-asam organik (Isroi, 2008).

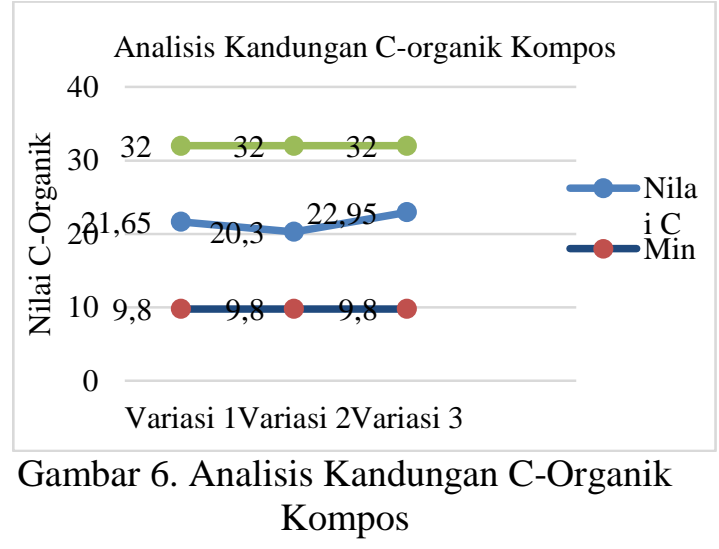

Berdasarkan hasil dari penelitian yang telah dilaksanakan didapatkan hasil pengukuran kandungan karbon memenuhi SNI 19-7030-2004 tentang kompos yaitu jika kandungan C-organik 9.80-32\%. Kandungan C-organik pada awal sludge sebelum dikompos sebesar $66 \%$. Setelah dikomposkan pada ketiga variasi tersebut kadungan C-Organik pada kompos matang mengalami penurunan. Sesuai dengan penelitian Riza miftahul,dkk (2018) bahwa selama proses composting semua reaktor akan mengalami penurunan. Hal ini terjadi karena selama proses composting kandungan karbon yang terdapat dalam bahan organik akan digunakan sebagai sumber energi untuk melakukan proses metabolisme. Bakteri akan terus menerus mengunakan karbon sumber energinya sehingga jumlah karbon yang terkandung dalam bahan composting akan terus berkurang ( Riza miftahul dkk, 2018).

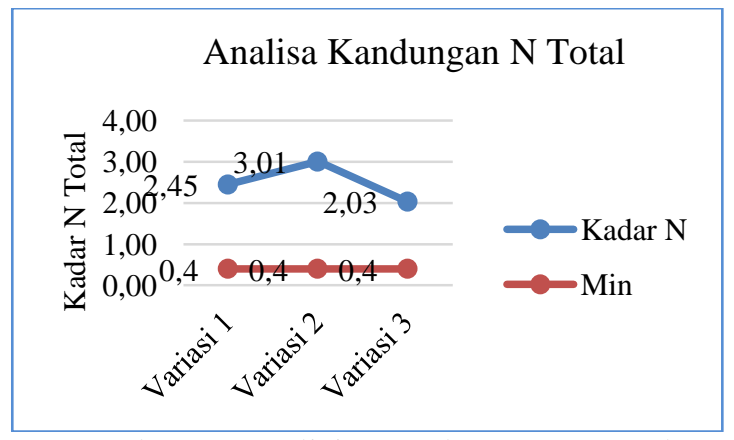

Gambar 7. Analisis Kandungan N Total

Berdasarkan hasil dari penelitian yang telah dilaksanakan didapatkan hasil pengukuran kandungan nitrogen yang didapatkan sudah memenuhi SNI 19-7030- 
2004 kompos dikatakan baik jika kandungan $\mathrm{N}$-Total $\geq 0.40 \%$, hasil yang didapatkan pada variasi 1 sebasar $2.450 \%$, variasi 2 sebesar $3.010 \%$, dan variasi 3 sebesar $2.030 \%$. Nitrogen adalah unsur utama dalam penyedian nutrisi tanaman. Pada sampel sludge sebelum dikompos nilai $\mathrm{N}$-total pada sludge sebesar 0.16 $\%$.Meningkatnya nilai nitrogen ini disebabkan oleh EM4 yang ditambahkan pada saat proses pengomposan. EM4 sebagai agen pendekomposisi bahan organik yang sesuai dengan penelitian Riza miftahul, dkk (2018) bahwa peningkatan kandungan N- total disebabkan adanya dekomposisi bahan organik tanah, pengikat oleh mikroorganisme, dan penambahan bahan organik yang mengandung $\mathrm{N}$ total tinggi. Mekanisme dekomposisi bahan organik menjadi nitrogen dalam tanah adalah melalui proses aminasi, amonifikasi dan nitrifikasi. Sedangkan penurunan kandungan N-Total disebabkan adanya kehilangan nitrogen dalam bentuk amoniak yang sangat mudah menguap ke udara sehingga kadar nitrogen menurun sementara terjadi proses nitrifikasi (Riza miftahul , 2018)

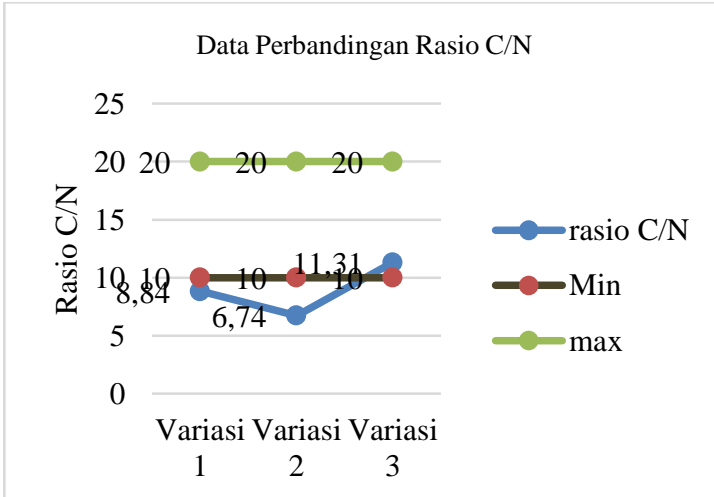

Gambar 8. Data Perbandingan Rasio C/N

Rasio $\mathrm{C} / \mathrm{N}$ merupakan perbandingan kadar Karbon $(\mathrm{C})$ dan kadar Nitrogen $(\mathrm{N})$ dalam suatu bahan. Berdasarkan hasil dari penelitian yang telah dilaksanakan didapatkan hasil rasio $\mathrm{C} / \mathrm{N}$ kompos pada variasi 1 dan 2 mengalami penurunan dan nilainya belum memenuhi standar SNI 197030-2004. Penurunan rasio $\mathrm{C} / \mathrm{N}$ disebabkan menurunnya kandungan COrganik dan meningkatnya kandungan $\mathrm{N}$ total pada bahan composting. Pada variasi 3 mengalami peningkatan yaitu 11.31 yang telah memenuhi SNI 19-7030-2004. Adanya peningkatan ini disebabkan jumlah C-organik yang tinggi sementara jumlah $\mathrm{N}$-total yang kecil dari variasi 1 dan 2 . Pada ketiga variasi didapatkan rasio $\mathrm{C} / \mathrm{N}$ $>20$ menyebabkan proses pengomposan lebih cepat. Ini sesuai dengan penelitian Saraswati, 2017 bahwa rasio C/N digunakan untuk mendapatkan degradasi biologis dari bahan organik yang sesuai untuk dijadikan kompos. Nilai rasio $\mathrm{C} / \mathrm{N}$ bahan organik sangat menentukan lama proses pengomposan. Proses pengomposan pada bahan organik dengan rasio $\mathrm{C} / \mathrm{N}>40$ lebih lama dibandingkan dengan rasio $\mathrm{C} / \mathrm{N}$ $>20$ (Saraswati, 2017).

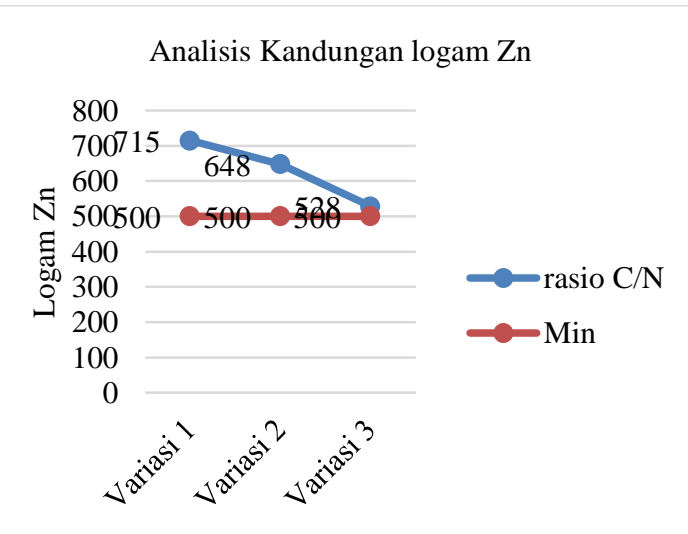

Gambar 9. Analisis Kandungan Logam Zn

Pada penelitian ini didapatkan kandungan logam Zn pada sludge yang tidak ditambah zeolite sebesar $714,79 \mathrm{mg} / \mathrm{kg}$ yang melewati ambang batas maksimal nilai logam Zn menurut SNI 19-7030-2004 yaitu $500 \mathrm{mg} / \mathrm{kg}$. Dari analisis logam berat pada kompos pemberian $10 \%$ zeolit pada proses pngomposan ternyata mampu menurunkan kandungan $\mathrm{Zn}$ menjadi $648,06 \mathrm{mg} / \mathrm{kg}$ yang mengurangi kandungan logam $\mathrm{Zn}$ sebesar 9,3\%. Pada penambahan $30 \%$ zeolite mampu menurunkan kadar $\mathrm{Zn}$ menjadi 528,31 $\mathrm{mh} / \mathrm{kg}$ yang mengurangi kabdungan $\mathrm{Zn}$ sebesar 26,1\%. Namun hasil tersebut 
belum memenuhi ambang batas maksimal SNI pada parameter logam Zn kompos.

\section{KESIMPULAN}

Dari hasil penelitian yang telah dilakukan, dapat disimpulkan bahwa :

1. Hasil penelitian ini menunjukan bahwa kompos dari sludge IPAL dengan penambahan zeolit $10 \%$ memenuhi 5 dari 9 parameter SNI kompos yang diuji yaitu nilai $\mathrm{pH}$, kadar air, temperatur, bau, dan warna. Penambahan $30 \%$ zeolite memenuhi 8 dari 9 parameter SNI yang diuji yaitu nilai $\mathrm{pH}$, kadar air, temperatur, bau, warna, $\mathrm{N}$ total, $\mathrm{C}$-Organik, Rasio $\mathrm{C} / \mathrm{N}$.

2. Pengunaan zeolit pada kompos memberikan pengaruh terhadap penurunan kandungan logam $\mathrm{Zn}$ pada kompos yang dihasilkan namun masih belum memenuhi SNI. Pada penggunaan $10 \%$ zeolit kadar $\mathrm{Zn}$ turun $9,3 \%$ dan pada penggunaan $30 \%$ zeolite kadar $\mathrm{Zn}$ turun $26,1 \%$.

\section{DAFTAR PUSTAKA}

Astiana Sustiono, 2004. Pemanfaatan Zeolit di Bidang pertanian. Jurnal Zeolit Indonesia. Vol. 3 No; 1 p; 3641

Ano.A.O.and

C.I.Ubochi.2007.

Neutralization of soil acidity by animal manures : mechanism of reaktion. Afirixa Journal Biotechnol. 6(4):364-368

Badan Standarisasi Nasional (BSN), SNI19-7030-2004:Spesifikasi

Kompos dari Sampah Organik Domestik,Bandung, 2001

[BPS] Badan Pusat Statistik. 2015. Statistik Kelapa Sawit Indonesia 2015. Badan Pusat Statistik. Jakarta.

Gunadi priyambada, Elvi Yenie, Ivnaini Andesgur, 2015. Studi Pemanfaatan Lumpur, Abu Boiler, dan Serat Fiber kelapa sawit sebagai kompos mengunakan varian Effective Microorganisme (EM-4), JOM FTEKNIK. Vol.2 No. 2 Riau

Haflan Erico Rambe, Elvi Yenie, Ivnaini Andesgur, 2016. Pengaruh variasi tinggi tumpukan pada proses pengomposan limbah lumpur sawit terhadap termofilik, JOM FTEKNIK. Vol.3 No. 2 Riau

Isroi, M, 2008. Makalah Kompos. Balai Penelitian bioteknologi perkebunan Indonesia, Bogor. http://.isoroi.org. Diakses pada tanggal 29 Mei 2020

Riza Miftahul Khair., dkk 2018. Pemanfaatan lumpur Wastewater Treatment Plant dan Abu boiler Industri Refinery dan Biodiesel Minyak Kelapa Sawit dengan Sistem in Vessel Composting. Jurnal Teknik Lingkungan.Vol. 2 No; 2

Saraswati R, Praptana RH. 2017. Percepatan proses pengomposan aerobik menggunakan biodekomposer. Jurnal Perspektif. Vol.16 No;1 p;44-56

Suwardi, 2009. Teknik Aplikasi Zeolit di Bidang Pertanian Sebagai bahan Pembenah Tanah. Jurnal Zeolit Indonesia. Vol. 8 No; 1 p; 33-38

Widyarini, W. 2008. Studi Kualitas Hasil Dan efektifitas Pengomposan secara Konvensional dan Model di TPA Temesi-gianyar, Bali. Denpasar.

Wildan Djaja. 2008. Membuat Kompos dari Kotoran Ternak \& Sampah. Jakarta: Agromedia.

Wahyono, Sri, dkk. 2003. Menyulap sampah menjadi kompos. Pusat pengkajian dan penerapan teknologi. Pusat dan penerapan teknologi lingkungan. Jakarta. 